\title{
STUDIES WITH INAGGLUTINABLE ERYTHROCYTE COUNTS. II. ANALYSIS OF MECHANISM OF COOLEY'S ANEMIA ${ }^{1}$
}

\author{
By HENRY E. HAMILTON, RAYMOND F. SHEETS, AND ELMER L. DeGOWIN \\ WITH THE TECHNICAL ASSISTANCE OF RUTH E. DAHLIN \\ (From the Department of Internal Medicine, State University of Iowa, University Hospitals, \\ Iowa City, Iowa)
}

(Submitted for publication May 19, 1949; accepted, February 17, 1950)

The fundamental nature of Cooley's anemia has not yet been determined. On the basis of clinical and hematologic studies several possible mechanisms for the production of this hereditary disorder have been suggested (1-4). The occurrence of jaundice and reticulocytosis points to a hemolytic type of anemia. It is unlikely that this is the only factor because bilirubinemia is not necessarily present and clinically there usually is an absence of acute hemolytic crises. It has been postulated that a metabolic disorder causes the production of defective erythrocytes because the autopsy picture is similar to that of hemochromatosis. The parenchyma of the organs contains abnormal amounts of iron and nonferrous pigments. The erythrocytes are small, bizarre in shape, and contain little hemoglobin. The defective erythrocytes are thought to be eliminated from the circulation more rapidly than normal cells.

There is also evidence to support the concept of a defect of maturation in the bone marrow. The marrow of severely anemic children presents a picture of hemopoietic arrest $(2,5-8)$ while the peripheral blood may be free of reticulocytes or nucleated red cells (8).

The experiments reported in this paper were devised to elucidate which of these various mechanisms causes the anemia. The following studies were made: $A$. The survival time of normal erythrocytes transfused to patients with Cooley's anemia and Cooley's trait. B. The survival time of cells from persons with Cooley's trait transfused to patients with Cooley's anemia and to normal subjects. $C$. An analysis of the data from a patient with Cooley's anemia to detect evidence indicating a depression of erythropoiesis or a rapid destruction of the recipient's cells. $D$. Erythropoiesis

\footnotetext{
1 The substance of this paper was delivered at the meeting of the American Society for Clinical Investigation at Atlantic City, N. J., on May 2, 1949.
}

after repeated phlebotomy was studied in a patient with Cooley's trait.

\section{METHODS}

The donor's blood was drawn into $3.2 \%$ sodium citrate solution $\left(\mathrm{Na}_{3} \mathrm{C}_{6} \mathrm{H}_{8} \mathrm{O}_{7}+2 \mathrm{H}_{8} \mathrm{O}\right)$ and stored at $4^{\circ} \mathrm{C}$. for a maximum of 18 hours before transfusion. In some instances the donor's cells were washed three times with sterile $0.9 \%$ sodium chloride solution. After the final centrifugation and removal of the supernatant fluid the cells were resuspended in isotonic saline solution and immediately transfused. The injection of blood by gravity required from 30 minutes to two hours.

The donor's cell counts after transfusion were measured by the Denstedt modification (9) of the Ashby differential agglutination technique. This method has been evaluated by us in another paper (10). Simultaneous counts of the inagglutinable cells and the total erythrocytes were obtained throughout the studies.

In these experiments blood from group $O$ donors was transfused to recipients of group A, except in one instance in which AN blood was transfused to an AM recipient. The differential agglutination technique was carried out with appropriate anti-A and anti-M sera.

A method described by us (10) was used to determine the rate of disappearance of the donor's cells and to analyze the net gain or deficit of the recipient's erythrocytes.

After withdrawing $500 \mathrm{ml}$. of blood from a patient with Cooley's trait frequent counts of reticulocytes and red cells were made.

The diagnosis of Cooley's anemia was based on the characteristic hematologic findings of anemia, a low mean concentration of corpuscular hemoglobin, a small mean corpuscular volume, decreased osmotic fragility of erythrocytes in hypotonic saline solution, microcytosis, anisocytosis, and poikilocytosis in the peripheral blood, and the occurrence of the characteristic trait in the father and mother. The diagnosis of Cooley's trait was based on the presence of similar hematologic findings, except that the erythrocyte counts were normal or increased. Other members of the family were demonstrated to have the trait (8).

\section{CLINICAL MATERIAL}

Case 1. J. Vos., Cooley's anemia, a male infant, aged seven weeks. The initial erythrocyte count was 2.7 mil- 
lions per mm. ${ }^{3}$; the hemoglobin was $8.9 \mathrm{gm}$. per $100 \mathrm{ml}$.; hematocrit (van Allen), $23 \%$; reticulocytes, $0.5 \%$; erythrocyte fragility in hypotonic saline solution, hemolysis began in $0.42 \% \mathrm{NaCl}$ and was complete in $0.18 \%$. The red cells of the peripheral blood showed anisocytosis, microcytosis, and poikilocytosis. The serum bilirubin was $0.2 \mathrm{mg}$. per $100 \mathrm{ml}$. and the van den Bergh reaction was

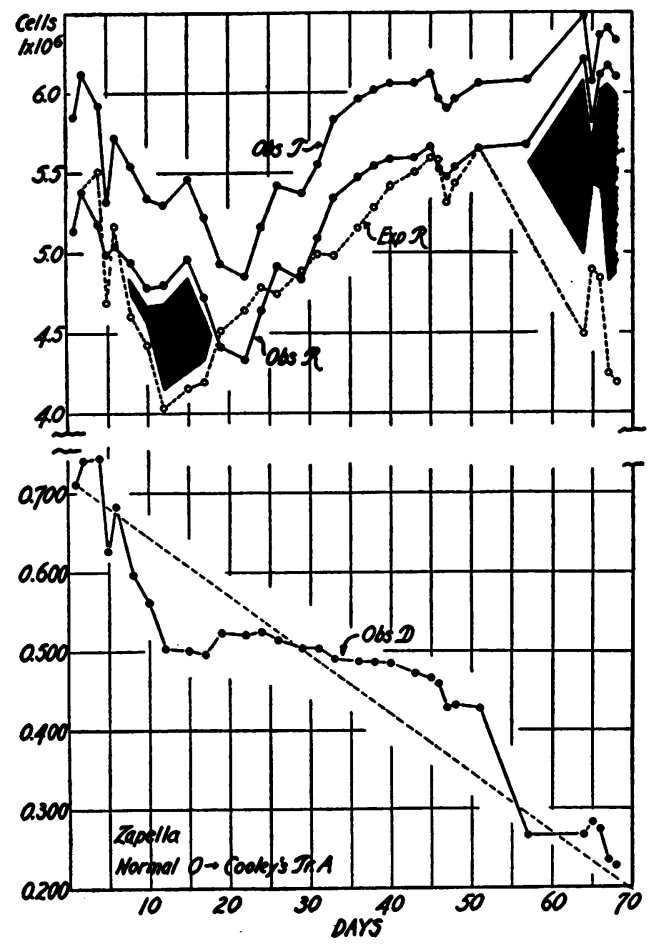

Fig. 1. Data from a Recipient with Cooley's Trait Belonging to Group A Who Was Given Blood from a Normal Group O Donor

The upper graph contains the plotted values for observed total cell count (obs $T$ ), the observed recipient's cell count (obs $R$ ), and the expected recipient's cell count (exp $R$ ). The lower graph, showing values for obs $D$ (observed donor's cell count), is constructed on a scale five times greater. The broken line intersects the $\mathrm{X}$ axis at 110 days, a normal survival rate. The black areas mark significant discrepancies between obs $R$ and $\exp R$, in both cases showing gains in the recipient's own cells. The earlier instance, beginning at the eighth day and extending to the 19th, is comparable to the posttransfusion gain seen in normal persons. The dip in the curve of obs $D$ from the sixth to the 25th day is apparently caused by the gain in the total number of recipient's cells coincident with an expansion of plasma volume. The subsequent rise of the values for obs $D$ above the expected coincides with a rise in the total cell count and is therefore caused by hemoconcentration. This recipient frequently had a spontaneous red cell count of over 6 millions per $\mathrm{mm}^{3}$ so that it was not considered that the transfusion produced an unaccustomed plethora.
TABLE I

Data of experiment in Figure 1 on transfusion of normal group 0 blood to group $A$ recipient with Cooley's trait

\begin{tabular}{|c|c|c|c|c|c|c|}
\hline $\begin{array}{l}\text { Time } \\
\text { after } \\
\text { trans- } \\
\text { fusion }\end{array}$ & $\mathbf{N}-\mathbf{n}$ & $\begin{array}{c}\text { Observed } \\
\text { total } \\
\text { cell } \\
\text { count } \\
\text { obs } T \\
10 \% / \mathrm{mm} .^{2}\end{array}$ & $\begin{array}{c}\text { Observed } \\
\text { donor's } \\
\text { cell } \\
\text { count } \\
\text { obs } D \\
10 \% / \mathrm{mm} .\end{array}$ & $\begin{array}{l}\text { Observed } \\
\text { recipient's } \\
\text { cell } \\
\text { count } \\
\text { obs } R \\
10^{6} / \mathrm{mm} .3\end{array}$ & $\begin{array}{c}\text { Expected } \\
\text { recipient's } \\
\text { cell } \\
\text { count } \\
\text { exp R } \\
10^{6} / \mathrm{mm} .\end{array}$ & $\begin{array}{c}\text { Twice } \\
\text { the } \\
\text { standard } \\
\text { error of } \\
\text { exp } R \\
10^{\circ} / \mathrm{mm} .\end{array}$ \\
\hline $\begin{array}{c}\text { days } \\
1 \\
2 \\
4 \\
5 \\
6 \\
8 \\
10 \\
12 \\
15 \\
17 \\
19 \\
22 \\
24 \\
26 \\
29 \\
31 \\
33 \\
36 \\
38 \\
40 \\
43 \\
45 \\
46 \\
47 \\
48 \\
51\end{array}$ & \begin{tabular}{|r|} 
days \\
110 \\
109 \\
107 \\
106 \\
105 \\
103 \\
101 \\
99 \\
96 \\
94 \\
92 \\
89 \\
87 \\
85 \\
82 \\
80 \\
78 \\
75 \\
73 \\
71 \\
68 \\
66 \\
65 \\
64 \\
63 \\
60 \\
54 \\
47 \\
46 \\
45 \\
44 \\
43
\end{tabular} & $\begin{array}{l}5.85 \\
6.12 \\
5.92 \\
5.32 \\
5.72 \\
5.54 \\
5.34 \\
5.30 \\
5.46 \\
5.22 \\
4.93 \\
4.85 \\
5.16 \\
5.42 \\
5.33 \\
5.55 \\
5.83 \\
5.96 \\
6.02 \\
6.06 \\
6.06 \\
6.12 \\
5.96 \\
5.90 \\
5.96 \\
6.06 \\
6.08 \\
6.48 \\
6.07 \\
6.36 \\
6.40 \\
6.33\end{array}$ & $\begin{array}{l}.712 \\
.740 \\
.743 \\
.626 \\
.682 \\
.596 \\
.562 \\
.502 \\
.500 \\
.496 \\
.523 \\
.520 \\
.524 \\
.507 \\
.504 \\
.503 \\
.489 \\
.486 \\
.485 \\
.484 \\
.471 \\
.465 \\
.457 \\
.428 \\
.431 \\
.427 \\
.265 \\
.266 \\
.283 \\
.274 \\
.235 \\
.227\end{array}$ & $\begin{array}{l}5.14 \\
5.38 \\
5.18 \\
4.69 \\
5.04 \\
4.94 \\
4.78 \\
4.80 \\
4.96 \\
4.72 \\
4.41 \\
4.33 \\
4.64 \\
4.91 \\
4.83 \\
\mathbf{5 . 0 9} \\
\mathbf{5 . 3 4} \\
\mathbf{5 . 4 7} \\
\mathbf{5 . 5 4} \\
\mathbf{5 . 5 8} \\
\mathbf{5 . 5 9} \\
\mathbf{5 . 6 6} \\
\mathbf{5 . 5 2} \\
\mathbf{5 . 4 7} \\
\mathbf{5 . 5 3} \\
\mathbf{5 . 6 3} \\
\mathbf{5 . 8 2} \\
\mathbf{6 . 2 1} \\
\mathbf{5 . 8 3} \\
\mathbf{6 . 1 1} \\
\mathbf{6 . 1 7} \\
\mathbf{6 . 1 0}\end{array}$ & $\begin{array}{l}5.39 \\
5.51 \\
4.69 \\
5.16 \\
4.60 \\
4.42 \\
4.03 \\
4.14 \\
4.19 \\
4.51 \\
4.64 \\
4.78 \\
4.74 \\
4.88 \\
4.99 \\
4.98 \\
5.15 \\
5.28 \\
5.41 \\
5.50 \\
5.59 \\
5.58 \\
5.31 \\
5.43 \\
5.65 \\
3.90 \\
4.49 \\
4.89 \\
4.84 \\
4.24 \\
4.19\end{array}$ & $\begin{array}{l}.163 \\
.167 \\
.148 \\
.167 \\
.136 \\
.132 \\
.128 \\
.136 \\
.142 \\
.153 \\
.167 \\
.176 \\
.184 \\
.200 \\
.214 \\
.224 \\
.251 \\
.270 \\
.286 \\
.319 \\
.340 \\
.351 \\
.345 \\
.363 \\
.412 \\
.354 \\
.489 \\
.542 \\
.556 \\
.508 \\
.519\end{array}$ \\
\hline
\end{tabular}

Reference day $=$ one day after transfusion; $N=110$ \pm 10 ; ref $D=0.712 \pm .010 ; \quad$ ref $R=5.14 \pm 0.120$; $2 \times \mathrm{SE}$ obs $\mathrm{T}=0.120 ; 2 \times \mathrm{SE}$ obs $\mathrm{D}=0.010 ; 2 \times \mathrm{SE}$ obs $\mathrm{R}=0.120$.

indirect. The blood was $\mathrm{AM}, \mathrm{Rh}$ o positive. The direct Coombs test was negative. The father and mother had the Cooley's trait and a four-year-old brother with Cooley's anemia had been treated with multiple blood transfusions. Erythrocyte survival studies were made continuously for one year on this patient.

Case 2. M. C., Cooley's trait, a young man, aged 20 years. The erythrocyte count was 4.34 millions per $\mathrm{mm}^{3}$. The hemoglobin was $10.2 \mathrm{gm}$. per $100 \mathrm{ml}$; the hematocrit (van Allen), 28\%; the osmotic fragility of the erythrocytes in hypotonic saline solution showed hemolysis beginning in $0.44 \% \mathrm{NaCl}$ and complete in $0.26 \%$. The serum bilirubin was $3.5 \mathrm{mg}$. per $100 \mathrm{ml}$, with an indirect van den Bergh reaction. The reticulocyte count was $0.9 \%$. The morphology of the peripheral red cells was characteristic. The blood was group $O$. The father and two sisters carried the Cooley's trait.

Case 3. D. C., Cooley's trait, a sister of M. C. (Case 2 ), in good health, aged 14 years. She had an erythro- 
cyte count of 4.36 millions per mm. ${ }^{3}$. The hemoglobin was $11.5 \mathrm{gm}$. per $100 \mathrm{ml}$. The hematocrit (van Allen) was $43 \%$. Hemolysis of erythrocytes in saline began in $0.42 \% \mathrm{NaCl}$ and was complete in $0.28 \%$. The serum bilirubin was $1.3 \mathrm{mg}$. per $100 \mathrm{ml}$. and gave an indirect van den Bergh reaction. The peripheral blood cells exhibited minimal microcytosis and anisocytosis. The patient belonged to blood group $\mathrm{O}$.

Case 4. D. Zap., Cooley's trait, a 22-year-old male student in excellent health. The erythrocyte count was 6.7 millions per mm. ${ }^{3}$. The hemoglobin was $11.9 \mathrm{gm}$. per $100 \mathrm{ml}$. The hematocrit (van Allen) was 30\%. Hemolysis of erythrocytes in hypotonic saline solution began in $0.44 \% \mathrm{NaCl}$ and was complete in $0.29 \%$. The serum bilirubin was $2.6 \mathrm{mg}$. per $100 \mathrm{ml}$., with an indirect van den Bergh reaction. The plasma iron was 265 gamma per $100 \mathrm{ml}$. The reticulocyte count was $0.7 \%$. The peripheral red cells exhibited the characteristic findings. The subject belonged to blood group A. The subject's daughter and brother were found to have Cooley's trait. This student had been a professional blood donor.
Case 5. L. Kruck., normal control, a year-old girl awaiting elective surgery for an anomaly of the bowel. She had normal hematologic values before transfusion. She belonged to blood group A.

Normal blood donors were members of the house staff of the University Hospitals.

\section{RESULTS}

Normal erythrocytes transfused to a patient with Cooley's trait (Figure 1 and Table I)

Five hundred ml. of blood were withdrawn from a subject with Cooley's trait (Case 4) who was then transfused with an equivalent amount of freshly collected group $O$ blood from a normal donor. An analysis by the method of DeGowin, Sheets and Hamilton (10) shows that the donor's cells were eliminated at a constant rate and disappeared from the circulation of the recipient in

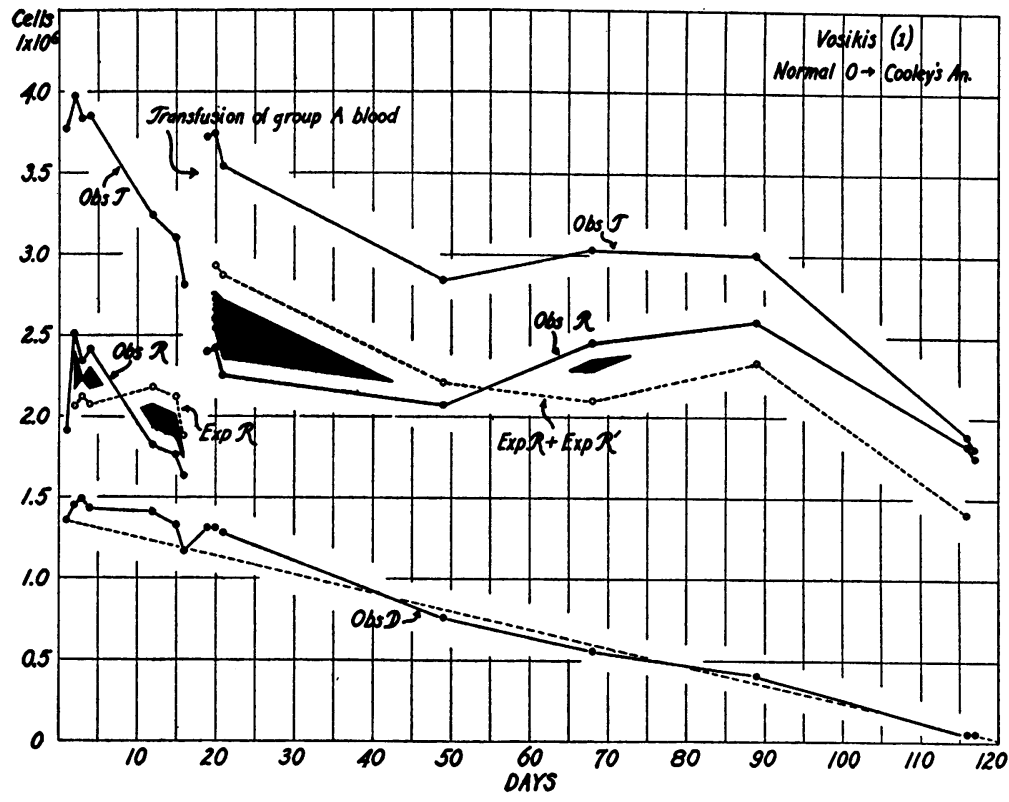

Fig. 2. Data from an Infant with Cooley's Anemia Belonging to Group a Who Received a Transfusion of Normal Group O Biood. ON the 19th Day of the Study a Transfusion of Group a Blood Was Given from Another Normal Donor.

The values for obs $T$, obs $R$, exp $R$, and $\exp R+\exp R^{\prime}$ are plotted in the upper graph and the observed values for the inagglutinable cell counts (obs $D$ ) occur in the lower part on the same scale. The inagglutinable cells disappear from the circulation in 120 days. In comparing obs $R$ with $\exp R$ it is seen that a brief period occurs, from the second to the sixth day, when there is a significant gain in recipient's cells (black area); this trend is quickly reversed and a deficit of $27 \%( \pm 7 \%)$ in recipient's cells developed by the 15th day. After the transfusion of blood of homologous group obs $R$ is compared with $\exp R+\exp R^{\prime}$ and it is seen that the deficit of recipient's cells persists until the 42 nd day. 
TABLE II

Data of experiment in Figure 2 on transfusion of normal group 0 blood to Cooley's anemia recipient of group $A$, with transfusion of blood from normal $A$ donor on 19 th day

\begin{tabular}{|c|c|c|c|c|c|c|c|c|c|c|c|}
\hline $\begin{array}{l}\text { Time } \\
\text { in } \\
\text { days }\end{array}$ & $\mathbf{N}-\mathbf{n}$ & $\mathrm{N}^{\prime}-\mathrm{n}^{\prime}$ & obs $\mathrm{T}$ & obs D & obs $\mathbf{R}$ & $\exp R$ & $\begin{array}{c}2 \mathrm{SE} \\
\exp R\end{array}$ & $\exp R^{\prime}$ & $\begin{array}{l}2 \mathrm{SE} \\
\exp \mathbf{R}^{\prime}\end{array}$ & $\begin{array}{l}\exp R_{+}^{+} \\
\exp R^{\prime}\end{array}$ & $\begin{array}{c}2 \mathrm{SE} \\
\exp R_{\exp R^{\prime}}\end{array}$ \\
\hline $\begin{array}{r}1 \\
2 \\
3 \\
4 \\
12 \\
15 \\
16 \\
19 \\
20 \\
21 \\
49 \\
68 \\
89 \\
116 \\
117\end{array}$ & $\begin{array}{r}122 \\
121 \\
120 \\
119 \\
111 \\
108 \\
107 \\
104 \\
103 \\
102 \\
74 \\
55 \\
34 \\
7 \\
6\end{array}$ & $\begin{array}{r}119 \\
118 \\
90 \\
71 \\
51 \\
24\end{array}$ & $\begin{array}{l}3.27 \\
3.97 \\
3.83 \\
3.85 \\
3.24 \\
3.10 \\
2.81 \\
3.72 \\
3.74 \\
3.54 \\
2.84 \\
3.03 \\
3.00 \\
1.89 \\
1.82\end{array}$ & $\begin{array}{l}1.358 \\
1.456 \\
1.490 \\
1.438 \\
1.414 \\
1.332 \\
1.178 \\
1.316 \\
1.318 \\
1.281 \\
0.763 \\
0.563 \\
0.406 \\
0.054 \\
0.052\end{array}$ & $\begin{array}{l}1.912 \\
2.514 \\
2.340 \\
2.412 \\
1.826 \\
1.768 \\
1.632 \\
2.404 \\
2.422 \\
2.259 \\
2.077 \\
2.467 \\
2.594 \\
1.836 \\
1.768\end{array}$ & $\begin{array}{l}2.06 \\
2.12 \\
2.07 \\
2.18 \\
2.12 \\
1.88 \\
2.17 \\
2.19 \\
2.15 \\
1.76 \\
1.75 \\
2.04 \\
1.32 \\
1.49\end{array}$ & $\begin{array}{l}.109 \\
.112 \\
.103 \\
.117 \\
.115 \\
.102 \\
.118 \\
.120 \\
.119 \\
.126 \\
.178 \\
.352 \\
.567\end{array}$ & $\begin{array}{l}.744 \\
.723 \\
.453 \\
.356 \\
.299 \\
.090\end{array}$ & $\begin{array}{l}.098 \\
.098 \\
.064 \\
.059 \\
.072 \\
.066\end{array}$ & $\begin{array}{l}2.93 \\
2.87 \\
2.21 \\
2.10 \\
2.34 \\
1.41\end{array}$ & $\begin{array}{l}.154 \\
.153 \\
.140 \\
.187 \\
.357 \\
.570\end{array}$ \\
\hline
\end{tabular}

Reference day $=$ one day after first transfusion; second reference day $=19$ days after first transfusion (immediately after second transfusion); $N=122 \pm 10 ; N^{\prime}=$ assumed $120 \pm 10 ;$ ref $D=1.358 \pm 0.020 ;$ ref $R=1.912 \pm 0.100 ;$ ref $\mathrm{R}^{\prime}=.659 \pm .086 ; 2 \times \mathrm{SE}$ obs $\mathrm{T}=0.120 ; 2 \times \mathrm{SE}$ obs $\mathrm{D}=0.020 ; 2 \times \mathrm{SE}$ obs $\mathrm{R}=0.120$

approximately 110 days. The deviations of the observed counts from a rectilinear curve can be adequately explained by plasma fluctuations or an overall increase in recipient's cells when the expected values for recipient's cell counts $(\exp R$ ) are compared with the observed values (obs $R$ ). This recipient frequently had a red cell count in the range of 6 millions per $\mathrm{mm}^{3}$ before transfusion so that the addition of the donor's cells did not clearly produce a polycythemia. The usual post-transfusion increase in recipient's cells occurred from the eighth to the 18th day. Another net increase in recipient's cells appeared on the 56th day and persisted to the 68th day when the error of computation became so large that no further comparisons were deemed valid.

This experiment shows that a subject with Cooley's trait did not destroy normal cells at an accelerated rate and he was able to produce his own cells in more than adequate numbers so that on two occasions he was able to attain a net gain in his own cells.

\section{Normal erythrocytes transfused to a patient with Cooley's anemia (Figure 2 and Table II)}

This was the first of three successive studies on erythrocyte survival carried on continuously for 357 days on an infant with severe Cooley's anemia (Case 1, Table IV). This patient had not received transfusions previously.
The patient was given a transfusion of group $\mathrm{O}$ blood from a normal donor. The curve of disappearance of the donor's cells in this experiment was rectilinear and the survival period of the inagglutinable erythrocytes was 120 days. On the 16 th and the 20th days transfusions of normal blood of the recipient's group were given to correct the anemia. Using the method of analysis previously described (10) it was found that there was a slight post-transfusion net increase in the recipient's cells from the second to the sixth day. From the 11 th to the 42 nd day there was a net deficit of recipient's cells. Between the fourth and the 15 th day a net deficit of $27 \%( \pm 7 \%)$ of the recipient's cells occurred. Choosing the conservative deficit of $20 \%$, it is calculated that all the recipient's cells would have disappeared from circulation in 44 days had the deficit increased at the rate recorded over this 11-day period. From the 20 th day to the 42 nd day the net deficit of recipient's cells was made up. After this and until the end of the experiment hemopoiesis compensated adequately for any loss of recipient's cells.

This experiment demonstrates that the patient with Cooley's anemia destroyed normal erythrocytes at a normal rate. A continuous period of 31 days was observed during which the patient with Cooley's anemia showed a net deficit in his own cells, suggesting an inadequate rate of hemopoiesis although there is no direct proof. This 
TABLE III

Data of experiment in Figure 3 on transfusion of blood of group 0 donor with Cooley's trait to normal recipient of group $A$

\begin{tabular}{|c|c|c|c|c|c|c|}
\hline $\begin{array}{l}\text { Time } \\
\text { after } \\
\text { trans- } \\
\text { fusion }\end{array}$ & $N-n$ & $\begin{array}{c}\text { Observed } \\
\text { total } \\
\text { cell } \\
\text { count } \\
\text { obs } T \\
10^{6} / \mathrm{mm} .\end{array}$ & $\begin{array}{l}\text { Observed } \\
\text { donor's } \\
\text { cell } \\
\text { count } \\
\text { fobs } D \\
10^{6} / \mathrm{mm} .^{3}\end{array}$ & $\begin{array}{l}\text { Observed } \\
\text { recipient's } \\
\text { cell } \\
\text { count } \\
\text { obs } R \\
10^{8} / \mathrm{mm} .^{8}\end{array}$ & $\begin{array}{l}\text { Expected } \\
\text { recipient's } \\
\text { cell } \\
\text { count } \\
\text { exp } R \\
10^{6} / \mathrm{mm}^{3}\end{array}$ & $\begin{array}{c}\text { Twice } \\
\text { the } \\
\text { standard } \\
\text { error of } \\
\text { exp } R \\
10^{8} / \mathrm{mm} . .^{8}\end{array}$ \\
\hline $\begin{array}{c}\text { days } \\
1 \\
8 \\
19 \\
33 \\
42 \\
57 \\
63 \\
65 \\
74 \\
79 \\
83 \\
90\end{array}$ & $\begin{array}{c}\text { days } \\
85 \\
78 \\
67 \\
53 \\
44 \\
29 \\
23 \\
21 \\
12 \\
7 \\
3\end{array}$ & $\begin{array}{l}5.94 \\
5.64 \\
5.09 \\
4.99 \\
5.04 \\
5.26 \\
5.29 \\
5.04 \\
5.06 \\
4.98 \\
4.70 \\
5.02\end{array}$ & $\begin{array}{r}1.084 \\
.993 \\
.894 \\
.586 \\
.507 \\
.284 \\
.207 \\
.188 \\
.093 \\
.053 \\
.038\end{array}$ & $\begin{array}{l}4.856 \\
4.647 \\
4.196 \\
4.404 \\
4.533 \\
4.976 \\
5.083 \\
4.852 \\
4.967 \\
4.927 \\
4.662\end{array}$ & $\begin{array}{l}4.847 \\
5.080 \\
4.210 \\
4.387 \\
3.728 \\
3.583 \\
3.408 \\
2.94 \\
2.88 \\
4.82\end{array}$ & $\begin{array}{r}.142 \\
.201 \\
.240 \\
.416 \\
.632 \\
.813 \\
.848 \\
1.208\end{array}$ \\
\hline
\end{tabular}

Reference day $=$ one day after transfusion; $\mathrm{N}=85$ \pm 10 ; ref $\mathrm{D}=1.084 \pm .020$; ref $\mathrm{R}=4.856 \pm .120$; $2 \times \mathrm{SE}$ obs $\mathrm{T}=.120 ; 2 \times \mathrm{SE}$ obs $\mathrm{D}=.020 ; 2 \times \mathrm{SE}$ obs $\mathrm{R}$ $=.120$.

was followed by a period of approximately 74 days during which the subject was able to replace his cells as fast as he lost them.

Erythrocytes from minimal Cooley's trait transfused to Cooley's anemia (Figure 6 and Table $I X$ of preceding paper [10])

In this experiment group $\mathrm{O}$ cells from a person with Cooley's trait (Case 3) were suspended in isotonic saline solution and transfused to the infant (Case 1), producing an unusually high inagglutinable cell count of about 2.8 millions per $\mathrm{mm}^{3}$. The curve of disappearance of the inagglutinable cells was rectilinear and the maximum survival time was 110 days (only the data of the first 38 days are shown in [10, Fig. 6]). There was no post-transfusion increase in recipient's cells and a net deficit developed on the 20th day which increased during the remainder of the period of study. A comparison of the observed recipient's cell count (obs $R$ ) and the expected recipient's cell count $(\exp R)$ on the 38th day shows a net deficit of recipient's cells of $43 \%( \pm 11 \%)$. The deficit occurred over a period of 18 days. Choosing the conservative deficit of $32 \%$ it is calculated that all the recipient's cells would have disappeared from circulation in 48 days had the deficit increased at the rate observed over this period.
This experiment shows a normal rate of loss of cells from a donor with minimal Cooley's trait in a recipient with Cooley's anemia. A short period of observation revealed a progressive deficit of recipient's cells.

\section{Erythrocytes from severe Cooley's trait trans- fused to Cooley's anemia (Figure 8 and Table $X$ of preceding paper [10])}

This was the final study in the infant with Cooley's anemia (Case 1). Washed group $\mathrm{O}$ cells from a donor with pronounced characteristics of Cooley's trait (Case 2) were divided into equal parts, one of which was transfused to the patient with Cooley's anemia and the other to a normal

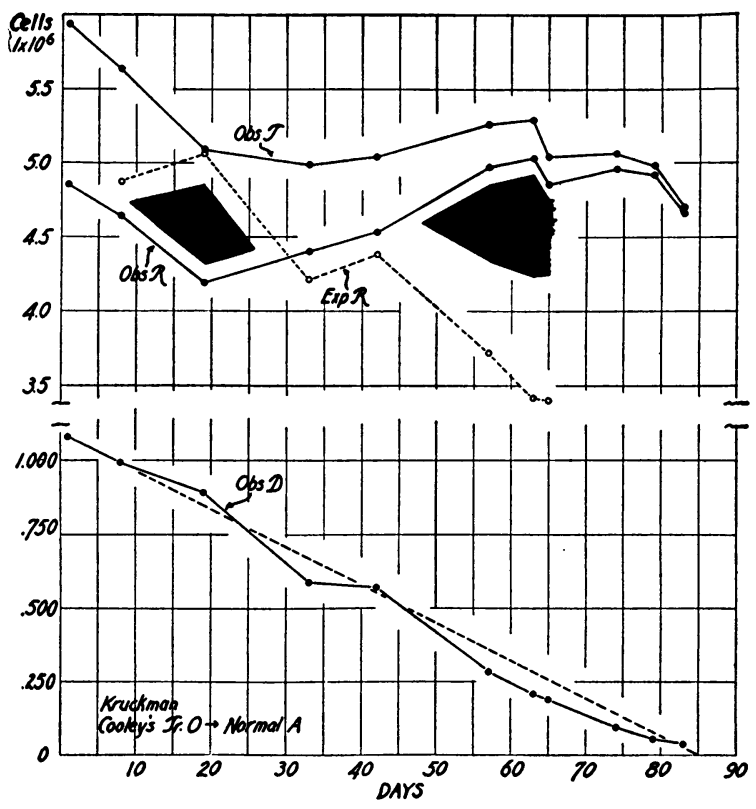

Fig. 3. Data from a Normal Child Belonging to Group A Who Received a Transfusion of Cells of Group O From a Donor with CoOley's Trait

In the upper graph are plotted the values for $o b s T$, obs $R$, and $\exp R$. The lower graph is constructed on a scale twice as large and contains the plotted values for obs $D$. The curve of $o b s D$ is essentially rectilinear and intersects the $\mathrm{X}$ axis at 85 days, indicating that the survival time of the cells from this particular donor with Cooley's trait are uniformly shortened. This recipient was made polycythemic by the transfusion ( $o b s T$ was 5.94 millions per mm. ${ }^{3}$ after transfusion) and comparison of obs $R$ with $\exp R$ shows a period from the ninth to the 26th day when there was a significant deficit of recipient's cells (black area) in contrast to the usual increase in recipient's cells seen after transfusion when polycythemic levels in the recipient have not been attained. 
recipient. On the 32 nd day it was necessary to give a transfusion of washed normal group A cells to the patient. The disappearance curve of the inagglutinable cells was rectilinear and the survival time was 100 days (slightly less than normal). There was no post-transfusion increase of recipient's cells. From the eighth day to the 67 th day there was a net deficit of recipient's cells. The expected recipient's counts were not computed after that time because the error of computation became excessive. On the 32 nd day the difference between the expected recipient's cell count (exp $R$ ) and the observed recipient's cell count (obs $R$ ) showed a net deficit of recipient's cells of $38.4 \%$ $( \pm 6.6 \%)$. In this instance the deficit occurred over a period of 25 days. Using the conservative deficit of $31.6 \%$ it is calculated that all the recipient's cells would have disappeared from the circulation in 69 days had the deficit increased at the rate observed over this period. During the last few days of the study the following reticulocyte counts in per cent were obtained: $0.9,0.9,1.3,0.5$,
1.0, 1.4, 2.0, 2.6, and 1. 4. The serum bilirubin was $1.0 \mathrm{mg}$. per ml., with an indirect van den Bergh reaction. The bone marrow presented a picture of maturation arrest (8).

\section{Erythrocytes of severe Cooley's trait transfused to normal subject (Figure 3 and Table III)}

A normal child (Case 5) belonging to group A received the other half of the washed group $O$ cells from the severe Cooley's trait used in the preceding experiment. The highest inagglutinable cell count was slightly in excess of one million per mm. ${ }^{8}$. The curve of elimination of the donor's cells was rectilinear. The survival period of the transfused cells was 85 days as compared with 100 days for the other half of the same cells in the patient with Cooley's anemia. Whether the difference in survival time of 15 days is significant is unknown, but both periods are probably shorter than normal.

The transfusion produced a temporary polycythemia with a maximum observed total erythro-

TABLE IV

Transfusion record of a patient with Cooley's anemia for 357 days

\begin{tabular}{|c|c|c|c|c|c|c|c|}
\hline \multirow{2}{*}{$\underset{\text { Day of }}{\text { Day orvation }}$} & \multirow{2}{*}{$\begin{array}{c}\text { Total } \\
\text { erythrocyte } \\
\text { counts } \\
10 \% / \mathrm{mm} .\end{array}$} & \multirow{2}{*}{$\begin{array}{l}\text { Recipient's } \\
\text { cell counts } \\
10^{6} / \mathrm{mm} .\end{array}$} & \multirow{2}{*}{$\begin{array}{l}\text { Inagglutinable } \\
\text { cell counts } \\
10 \% / \mathrm{mm} .8\end{array}$} & \multirow{2}{*}{$\begin{array}{c}\text { Body } \\
\text { weight }\end{array}$} & \multicolumn{3}{|c|}{ Blood transfusions } \\
\hline & & & & & Volume & Group & Status of donor \\
\hline $\begin{array}{r}0 \\
2 \\
16 \\
16 \\
19 \\
20 \\
21 \\
117 \\
117 \\
\\
118 \\
155 \\
155 \\
155 \\
208 \\
208 \\
209 \\
229 \\
251 \\
251 \\
253 \\
283 \\
284 \\
284 \\
354 \\
355 \\
356 \\
357\end{array}$ & $\begin{array}{l}2.77 \\
3.97 \\
2.81 \\
3.72 \\
3.54 \\
1.82 \\
\\
4.50 \\
2.61 \\
\\
4.28 \\
2.17 \\
\\
5.32 \\
4.25 \\
2.86 \\
3.78 \\
2.17 \\
6.01 \\
2.37 \\
2.23 \\
2.32 \\
2.34\end{array}$ & $\begin{array}{l}2.514 \\
1.632 \\
2.404^{*} \\
2.259^{*} \\
1.768^{*} \\
\\
1.708 \\
0.897 \\
\\
1.786^{*} \\
4.864^{*} \\
4.18^{*} \\
2.86^{*} \\
2.65^{*} \\
1.464 \\
5.410^{*} \\
2.350 \\
2.230^{*}\end{array}$ & $\begin{array}{l}1.456 \\
1.178 \\
1.316 \\
1.281 \\
0.052 \\
\\
2.792 \\
1.713 \\
\\
0.384 \\
0.456 \\
0.070 \\
0 . \\
1.130 \\
0.706 \\
0.594 \\
0.016 \\
0 .\end{array}$ & $\begin{array}{l}\text { kg. } \\
4.3 \\
4.8\end{array}$ & $\begin{array}{r}m l . \\
90 \\
105 \\
150 \\
210\end{array}$ & $\begin{array}{l}0 \\
\text { A } \\
\text { A } \\
0\end{array}$ & 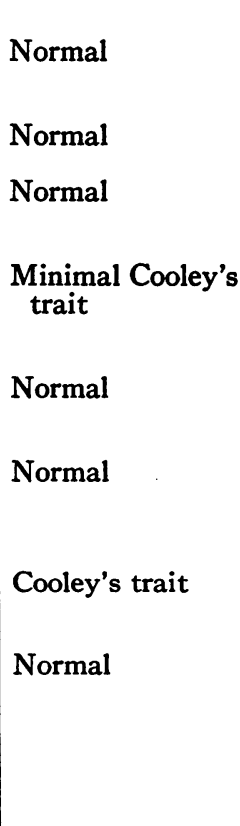 \\
\hline
\end{tabular}

* These counts include not only the erythrocytes of the recipient but group A cells transfused at various times. 
cyte count of 5.94 millions per mm. ${ }^{3}$. Perhaps as a result of the induced polycythemia, a net deficit of recipient's cells was apparent from the ninth to the 26th day. From the 48th to the 65 th day there was a net gain in recipient's cells. The expected values later were not computed because of the excessive error of computation.

This experiment demonstrates that the cells of a subject with severe Cooley's trait have a shortened survival time in a normal recipient as compared with the normal survival period of cells of a minimal Cooley's trait (10, Fig. 8).

\section{Erythropoiesis in subject with Cooley's trait after repeated donations of blood}

Further insight into the problem of erythropoietic activity was gained by studying a subject with a pronounced Cooley's trait after phlebotomy. The subject (Case 4) had been a professional blood doner. He gave five transfusions of $500 \mathrm{ml}$. each in 16 months and experienced no ill effects following blood donation. When he came under our observation his total erythrocyte counts ranged between 6.0 and 7.0 million per $\mathrm{mm}^{3}$. In Table $\mathrm{V}$ is a compilation of hematologic values obtained after $500 \mathrm{ml}$. of blood were removed from this subject. Four days afterward his total erythrocyte count had fallen $1,000,000$ per $\mathrm{mm}^{3}$ On the 19 th day the cell count had returned to the level before blood donation. From the fourth through the 19th day there was a reticulocytosis.

The father of the boy in Case 1 had given 10 transfusions of $500 \mathrm{ml}$. of blood each in a period of three years and had suffered no apparent ill effect, although he was known to have the Cooley's trait (8).

TABLE $v$

Recovery of a person with Cooley's trait from blood loss

\begin{tabular}{c|c|c|c}
\hline $\begin{array}{c}\text { Day after } \\
\text { Dhlebotomy }\end{array}$ & $\begin{array}{c}\text { Erythrocyte } \\
\text { counts } \\
\text { 10/mm. }\end{array}$ & $\begin{array}{c}\text { Reticulocytes } \\
\%\end{array}$ & $\begin{array}{c}\text { Serum } \\
\text { bilirubin* }\end{array}$ \\
\hline 0 & 6.76 & 0.8 & \\
2 & 6.56 & 0.7 & \\
4 & 5.56 & 1.1 & 1.8 \\
7 & 5.90 & 1.3 & \\
9 & 6.11 & 1.1 & \\
13 & 6.66 & 2.0 & \\
19 & 6.74 & 1.1 & 2.0 \\
38 & 6.44 & 0.4 & 1.0 \\
45 & 6.74 & 0.4 & \\
\hline
\end{tabular}

* All samples of serum gave the indirect van den Bergh reaction.

\section{DISCUSSION}

\section{The hemolytic aspect of Cooley's anemia and Cooley's trait}

Evidence has been presented that the survival period of the cells in one case of Cooley's anemia was shorter than normal. Because of the precarious state of the infant patient we were unwilling to employ him as a donor. It was therefore necessary to use indirect methods of study to estimate the survival time of his cells. The patient was studied for a period of 357 days during which time he received eight blood transfusions, three of which were with biologically tagged cells. Frequent examinations in the clinic and hospital provided many clinical and laboratory data.

An analysis of the data in Figures 6 and 8 of the preceding paper (10) and Figure 2 of this paper reveals prolonged periods of net deficit of the cells of the patient with Cooley's anemia during which it was calculated that the maximum survival period of the Cooley's anemia cells was 44, 48, and 69 days, respectively. These are shortened survival periods. In Figure 2 and Table IV it is clear that the patient was able to maintain his own erythrocyte count at a minimum of 897,000 per mm. ${ }^{3}$.

It is unlikely that the deficit of cells in Cooley's anemia is due to an acute hemolytic process because at no time was a hemolytic crisis observed in this subject. With a falling erythrocyte count the serum bilirubin level was as low as $0.2 \mathrm{mg}$. per $100 \mathrm{ml}$., with an indirect van den Bergh reaction, while bilirubin values ranging from $1.0 \mathrm{mg}$. to 3.0 $\mathrm{mg}$. per $100 \mathrm{ml}$. were obtained during a period of accelerated erythropoiesis.

Since it has been shown in the experiments that the rate of disappearance of the transfused cells was rectilinear, it is assumed that each erythrocyte had approximately the same life span. It was first pointed out by Brown and his associates (11) that there are two types of elimination curves. The rectilinear type is explained by the assumption that each erythrocyte has the same life span. The curvilinear type assumes a destructive mechanism which is independent of the age of the cell. The first mechanism appears to obtain in these studies.

The work of Dacie and Mollison (12), Mollison (13), Brown and his coworkers (11), and Mollison (14) has defined two main kinds of hemolytic 
anemia. $A$. The patient's own cells, as well as any erythrocytes transfused into his circulation, are destroyed at an accelerated rate. $B$. The defective erythrocytes of the patient are destroyed more rapidly than usual but normal erythrocytes survive a normal time in the circulation of the patient. Mollison (13) demonstrated by erythrocyte survival studies that acquired hemolytic anemia belongs in the former group whereas familial hemolytic jaundice falls in the latter group.

Thus, the results of our studies revealed a normal survival of normal erythrocytes in a patient with Cooley's anemia and a subject with Cooley's trait, and a shortened survival period of cells from Cooley's trait and Cooley's anemia. It therefore appears that the shortened life span in this disorder is incident to a defect in the subject's cells.

\section{The erythropoietic factor in the production of the anemia}

The anemia in the Cooley's state does not depend solely upon a shortened life span of the erythrocyte but is probably secondary to a partial hemopoietic arrest, alternating with periods of active erythropoiesis. The conclusion is based upon the following clinical and laboratory observations: (a) acute hemolytic crises were absent; (b) the marrow cells of the bone presented a picture of a maturation arrest (8), and (c) reticulocytes were few or absent in the peripheral blood while the subject's red cell count was falling, whereas reticulocytosis was noted while the subject's cell counts were rising or remained constant. Such relations have been observed in two subjects with Cooley's anemia (8).

A continuous study for nearly a year with inagglutinable erythrocytes in a patient with Cooley's anemia permitted measurements of net deficit and gain of the subject's erythrocytes. The results indicate that variable degrees of depression of the erythropoietic tissue are sufficient to cause the ane$\mathrm{mia}$ in this disorder.

It appears from these data that the anemia is primarily due to diminished activity of the marrow and that in our subject erythropoiesis was unable to sustain an erythrocyte count of more than 1.5 millions per $\mathrm{mm}^{3}$. On the other hand, the erythropoietic activity of a subject with Cooley's trait is adequate to replace lost cells and to maintain a normal or high total count, even though the survival time of the trait cell is shorter than normal. Furthermore there is the capacity rapidly to replace cells lost in hemorrhage.

The clinical observation (4) that a gradation of severity exists in this disorder, ranging from the severe Cooley's anemia to an extremely mild trait, can more readily be explained on a variable degree of erythropoietic depression than on the basis of a hemolytic process alone.

\section{Subjects with Cooley's trait as blood donors}

Since a large number of persons of Italian and Greek ancestry have the Cooley's trait (14) the advisability of using their blood for transfusion must be considered. Our experience with two donors suggests it is permissible. The blood from subjects with Cooley's trait has not been known to produce hemolytic transfusion reactions. After transfusion of blood from a donor with Cooley's trait (Case 4) to a normal adult frequent estimations of serum bilirubin and hemochromogens failed to show evidence of abnormal hemolysis. Two subjects with Cooley's trait recovered rapidly from repeated donations of $500 \mathrm{ml}$. of blood. The survival time of trait cells may be somewhat shorter than normal but, for many purposes, this fact may not be important. Provided the person with Cooley's trait meets the usual qualifications for blood donors, there seems to be no danger from the donation of blood and little contraindication to its use in transfusion.

\section{SUMMARY}

1. Normal erythrocytes transfused to a patient with Cooley's anemia and to a subject with Cooley's trait survived a normal length of time.

2. Erythrocytes from a subject with minimal Cooley's trait transfused to a patient with Cooley's anemia survived a normal length of time.

3. The survival period of the cells of a more severe Cooley's trait was found to be shorter than normal ( 85 days) when transfused to a normal person. Cells from the same donor were found to have a survival period in the lower range of normal (100 days) when transfused to a patient with Cooley's anemia.

4. In each of these studies the disappearance curve of the transfused cells was found to be rectilinear. 
5. The survival period of the cells of Cooley's anemia was calculated to be shorter than normal.

6. Frequent periods of net deficit of his own erythrocytes were demonstrated in a patient with Cooley's anemia.

7. The rapid recovery from acute blood loss in subjects with Cooley's trait is discussed.

\section{CONCLUSIONS}

These data support the hypothesis that the disorder in Cooley's trait is due to an intrinsic defect in the erythrocyte which shortens its survival in the circulation. Increased erythropoiesis, however, compensates for the loss of red cells.

When the possession of this type of defective erythrocyte is combined with an insufficient rate of erythropoiesis the state of Cooley's anemia is produced.

\section{ACKNOWLEDGMENT}

The authors wish to express their appreciation to Drs. J. D. Boyd and J. C. MacQueen (Department of Pediatrics) and to Dr. E. S. Brintnall (Department of Surgery) for the opportunity to study the patients in Case 1 and Case 5, respectively.

\section{BIBLIOGRAPHY}

1. Cooley, T. B., Witwer, E. R., and Lee, P., Anemia in children with splenomegaly and peculiar changes in the bones. Report of cases. Am. J. Dis. Child., 1927, 34, 347.

2. Whipple, G. H., and Bradford, W. L., Racial or familial anemia of children associated with fundamental disturbance of bone and pigment metabolism (Cooley-Von Jaksch). Am. J. Dis. Child., 1932, 44, 336.
3. Wintrobe, M. M., Matthews, E., Pollack, R., and Dobys, B. M., A familial hemopoietic disorder in Italian adolescents and adults resembling Mediterranean disease (Thalassemia). J.A.M.A., 1940, 114, 1530.

4. Dameshek, W., Familial Mediterranean target-oval cell syndromes. Am. J. M. Sc., 1943, 205, 643.

5. Vogel, P., and Bassen, F. A., Sternal marrow of children in normal and pathologic states. Am. J. Dis. Child., 1939, 57, 245.

6. Diwani, M., Erythroblastic anaemia with bone changes in Egyptian children; possible Cooley's type. Arch. Dis. Childhood, 1944, 19, 163.

7. Fawdry, A. L., Erythroblastic anaemia of childhood (Cooley's anaemia) in Cyprus. Lancet, 1944, 1, 171.

8. Hamilton, H. E., and Fowler, W. M., A clinical and genetic study of three families with Mediterranean anemia (Cooley's anemia and Cooley's trait). To be published.

9. Osborne, D. E., and Denstedt, O. F., Estimation of cell survival after transfusion by selective agglutination. J. Clin. Invest., 1947, 26, 655.

10. DeGowin, E. L., Sheets, R. F., and Hamilton, H. E., Studies with inagglutinable erythrocyte counts. I. A method for measurement of net gain or deficit of red cells in the human subject. J. Clin. Invest., 1950, 29, 693.

11. Brown, G. M., Hayward, O. C., Powell, E. O., and Witts, L. J., The destruction of transfused erythrocytes in anaemia. J. Path. \& Bact., 1944, 56, 81.

12. Dacie, J. V., and Mollison, P. L., Survival of normal erythrocytes after transfusion to patients with familial haemolytic anaemia. Lancet, 1943, 1, 550.

13. Mollison, P. L., The survival of transfused erythrocytes in haemolytic disease of the newborn. Arch. Dis. Childhood, 1943, 18, 161.

14. Mollison, P. L., The survival of transfused erythrocytes, with special reference to cases of acquired haemolytic anaemia. Clin. Sci., 1947, 6, 137. 